\title{
A loquela amorosa de André Gorz
}

Carta a D.: história de um amor.

GORZ, André.

Tradução de Celso Azzan Jr.

São Paulo: Annablume; Cosac Naify, 2008. $78 \mathrm{p}$.

Como Ecléa Bosi coloca na orelha do livro Carta a D.: história de um amor, em tempos de Ditadura Militar no Brasil ter um livro de André Gorz era, por si, um ato subversivo. Jornalista, sociólogo e filósofo, tão multifacetado quanto "multinomeado",' André Gorz foi, sem sombra de dúvidas, um dos grandes responsáveis por moldar os caminhos da nova esquerda na segunda metade do século $X X$, influência que obviamente não se restringe à França.

Judeu austríaco nascido em 1923, imigrou para a Suíça aos 15 anos fugindo do nazismo. Anos depois, já formado engenheiro químico, erradicou-se na França e passou a trabalhar como jornalista para grandes revistas de esquerda como Les Temps Modernes e Le Nouvel Observateur. Como salienta Josué da Silva Pereira no posfácio desse livro, Gorz foi profundamente influenciado pelos escritos de Karl Marx e JeanPaul Sartre e buscava compreender questões caras ao socialismo como sindicalismo e trabalho, tornando-se um dos expoentes do marxismo existencialista. Já na década de 1970, influen- 
ciado pelas ideias de Ivan Illich, passa a focar-se na questão da ecologia - se tornando um dos fundadores da chamada ecologia política -, percebendo "a irracionalidade da racionalidade capitalista em suas diferentes dimensões, da destruição do ambiente natural à mercantilização das relações sociais". ${ }^{2}$ Por esse caminho, posteriormente, rompe definitivamente com 0 marxismo com o livro polêmico Adeus ao proletariado.

Autor de mais de 20 livros (sendo apenas oito publicados no Brasil) e de inúmeros artigos, a trajetória político-filosófica de Gorz remonta de modo bastante contundente os caminhos trilhados pelo pensamento de esquerda francês na última metade do século passado. Contudo, já em seu último livro, escrito como uma carta para sua companheira por 58 anos, Dorine, André Gorz escolhe abordar uma dimensão da vida marginalizada pelas correntes de pensamento das quais ele foi expoente: 0 amor.

Você está para fazer oitenta e dois anos. Encolheu seis centímetros, não pesa mais do que quarenta e cinco quilos e continua bela, graciosa e desejável. Já faz cinquenta e oito anos que vivemos juntos, e eu amo você mais do que nunca. De novo, carrego no fundo do meu peito um vazio devorador que somente $o$ calor do seu corpo contra o meu é capaz de preencher (p. 5).

É com essa declaração que Gorz dá início ao projeto autorreflexivo que desenvolve nessa curta narrativa em que autor, vida e obra se misturam à moda existencialista.

Relembrando e recontando a trajetória que traçou junto com sua esposa, o autor busca compreender a história que viveram juntos e que permitiu, em suas palavras, tornarem-se o que são. Sua pergunta principal é "Por que você [Dorine, sua esposa por mais de cinco décadas] está tão pouco presente no que escrevi, se a nossa união é o que existe de mais importante na minha vida?" (p. 5). Assim, desde suas primeiras linhas se anuncia que o exercício feito pelo autor aqui não é um simples recontar e relembrar, mas é fruto principalmente de uma dura constatação sobre a maneira como encarou seu casamento, sua companheira - e o amor, de modo geral por toda sua vida.

Para isso, ele começa do começo; da primeira vez que a viu, dos primeiros encontros, do encantamento inicial por essa jovem atriz inglesa inteligente $e$ independente, da descoberta do sexo e do prazer. ${ }^{3} \mathrm{O}$ tom é sempre de assombro, de maravilhamento com a mulher amada e perplexidade no seu interes- se por ele, "An austrian jew. Totally devoid of interest" (p. 7). A idealização e a singularização de Dorine - típicas do amor romântico como analisado por Giddens ${ }^{4}$ - se associam à ideia de uma experiência fundadora desse amor, a da insegurança e falta de "lugar no mundo" que se resolve pela construção desse lugar pelo e no casal:

Nós éramos, eu e você, filhos da precariedade e do conflito. Fomos feitos para nos proteger mutuamente contra ambos, e precisávamos criar juntos, um pelo outro, o lugar no mundo que originalmente nos tinha sido negado. Para isso, no entanto, seria necessário que o nosso amor fosse também um pacto para a vida inteira (p. 15, grifo do autor).

O casamento, como era de se esperar, foi assunto polêmico para o casal: para $\circ$ jovem Gorz, não passava de uma instituição pequenoburguesa que codificava juridicamente e socializava uma relação entre pessoas no que essa tinha de menos social, o amor. Dorine, como Gorz conta, argumentava que o casamento significava que estavam comprometidos com esse "pacto para a vida inteira, que os tornaria o que fizessem juntos" (p. 18). Assim, por fim, Dorine o convence ao casamento no final da década de 1940.

Em 1949 deixam Lausanne em direção a Paris devido a uma oferta de trabalho que Gorz recebe para ser secretário do secretário internacional do Citoyens du Monde, ${ }^{5}$ trabalho do qual Dorine toma grande parte, participando da redação das circulares em inglês e recebendo estrangeiros que visitavam o escritório. "Você assumia a sua parte no trabalho que eu tinha que fazer", afirma Gorz para Dorine. Apesar de trabalharem conjuntamente, o trabalho continua sendo dele, há claramente uma divisão conjugal do trabalho, mas jamais da autoria. A constatação tardia dessa desigualdade é, a meu ver, um dos pontos-chaves da autorreflexão do autor.

É nessa mesma época que Gorz passa a se dedicar intensivamente aos escritos que construiriam seu primeiro livro (Le Traite, 1958). Quanto a isso ele ressalta a cumplicidade e a compreensão que sua amada tomava nesse processo: "Amar um escritor é amar que ele escreva', dizia você. 'Então escreva!'” (p. 28). A publicação de Le Traite é crucial para Gorz, que vê nesse evento o estabelecimento de um lugar no mundo para si através da realidade conferida pela prensa às suas ideias. Ao mesmo tempo, "ser publicado" Ihe faz perceber como "sempre restará tudo a dizer" (p. 46); tudo isso 
que resta é, em parte, o que ele se dá conta ao reler o capítulo do livro intitulado "Você".

Em sua releitura, Gorz afirma que o capítulo deveria abordar a descoberta do amor com Dorine, como esse amor se tornava uma conversão existencial, mas, em troca, nele ele tê-la-ia retratado com "uma espécie de condescendência leviana". A resposta para essa postura é dada pelo próprio autor, que assume considerar então o amor - em especial o amor que sentia por ela - como uma fraqueza e de ser motivado obsessivamente por uma "distância objetivadora" que o permitiria elevar-se sobre o que vive e perceber puramente a teoria. Amar e ser amado the parecia uma experiência banal demais, particular demais, uma matéria pouco apropriada para a elucubração teórica, para "atingir o universal". "Meu amor por você não ama a si mesmo" (p. 54).

E então veio o "Maio de 68". O casal, como conta Gorz, recebeu os novos movimentos de braços abertos, e os trabalhos do autor (percebidos sempre como sendo apenas seus) foram apontados como precursores para esses novos ares. Na década de 1970 o casal passa a viajar pelos Estados Unidos e pela Europa, convivendo em meios acadêmicos e descobrindo pessoas que procuravam viver juntas de formas diferentes, perseguindo seus fins alternativos. "Nunca tínhamos visto tantos existencialistas" (p. 58), afirma Gorz ironicamente. Diante dessas novas influências, Gorz percebe que lutas sociais se movem para novos terrenos para além da luta de classes. A partir das leituras e da amizade com Ivan Illich, questões como a autogestão tomam lugar importante em sua vida, tanto na produção teórica quanto na vida prática, motivando-o não apenas a tomar outros rumos em seus escritos, mas também a projetar e construir uma casa junto com Dorine, em forma de U. A ecologia política passa a ocupar um lugar central para o casal.

Em 1973, após sofrer com fortes dores de cabeça, o casal descobre que Dorine tem aracnoidite, uma afecção evolutiva sem tratamento fruto de uma injeção de contraste (lipiodol) para radiografia que nunca se dissolveu. A tecnocrítica toma outro peso na história. Revoltados com a medicina, Dorine passa a se dedicar a tratamentos alternativos, homeopatia, alimentação orgânica e meditação para controlar as dores; Gorz, já no terreno da ecologia, pesquisa sobre medicinas alternativas e alguns anos depois pede aposentadoria (aos 60 anos, em 1983) para se dedicar ao cuidado e à companhia da amada.
"Eu queria acreditar que nós tínhamos tudo em comum, mas você estava sozinha na sua aflição" (p. 62).

A carta acaba em 6 de junho de 2006 , não menos emocionante do que como começa. Nesse meio-tempo Gorz produziu vastamente e o casal recebeu inúmeras visitas em sua casa no interior da França, mas agora ambos passam dos 80 e o autor vislumbra a morte próxima da amada fragilizada pela doença. "À noite eu vejo, às vezes, a silhueta de um homem que, numa estrada vazia e numa paisagem deserta, anda atrás de um carro fúnebre. Eu sou esse homem. É você que esse carro leva" (p. 70).

Esse é o fim da narrativa, mas para qualquer leitor de Carta a $D$. não é o fim da história. No ano seguinte, em 22 de setembro de 2007, com o livro já publicado na França, o casal é encontrado morto, de mãos dadas, na cama em sua casa em Vosnon. Eles haviam se suicidado com injeções letais, deixando várias cartas para amigos, polícia e imprensa.

A carta certamente não é um bilhete de suicídio ou, como sugere o subtítulo da edição brasileira, uma simples história de um amor. Ela é um desnudamento de um eu, de um nós, feito à crua luz da memória. Lembrar é sempre escolher, recontar, reformular o passado de modo a torná-lo coerente com algum objetivo presente; Gorz faz aqui a retratação de um retrato. O marxista existencialista dos 30 anos percebia e escrevia o amor e a amada como fraquezas; o esposo ecologista dos 80 anos vê essa relação como a mais importante de sua vida, a que o fez o que é, e as lembranças narradas no livro são narradas desse ponto de vista.

Dorine é no livro o próprio atopos sugerido por Barthes: ${ }^{6}$ uma mulher inclassificável, a própria singularidade e originalidade aos olhos do apaixonado Gorz. Redimindo-se da maneira como a pintou em obras anteriores - como uma mocinha frágil e perdida que não sobreviveria sem ele, como ele mesmo coloca -, ele a retrata agora como independente, inteligente e livre, que o supera em todas as suas capacidades $e$ que teve um papel essencial no pensamento que ele criou. Nesse sentido, os contornos da autoria, do eu e do você, são embaçados na narrativa, uma vez que essa oscila entre a primeira pessoa do singular e a primeira pessoa do plural. As lembranças, os trabalhos, os engajamentos políticos e as amizades, todos são do nós. É o eu que pede desculpas pela postura intransigente do passado, que ama e que sofre com a perspectiva de perda da mulher amada. 
Em sua pequena edição - emocionante desde o cuidado com a capa até os textos de posfácio e orelha de Josué Pereira da Silva e Ecléa Bosi e a tradução cuidadosa de Celso Azzan Jr. -, Carta a $D$. é, além de um discurso sobre amar - e tudo o que isso significa -, um retrato especial das formas pelas quais se desenharam relações afetivas a partir de relações de gênero em camadas médias e intelectualizadas no século XX. É forte a impressão que fica após a leitura de como o trabalho que Dorine exerceu juntamente com o marido passou sem reconhecimento. Reduzida a uma função de assistente, há sempre na narrativa a imagem de que ela "se entretinha intelectualmente" (participando das pesquisas do marido, lendo e fazendo cursos), enquanto ele "trabalhava intelectualmente", o que em muito lembra a análise de Mariza Côrrea ${ }^{7}$ sobre o caso de esposas de antropólogos que, apesar de também irem a campo e trabaIharem, tinham sua importância obscurecida pela fama do companheiro (como o caso de Dina, esposa de Claude Lévi-Strauss, tão bem retrata).

É certo que o desfecho dramático e romântico - para não dizer, Romeu e Julieta ${ }^{8}$ impulsionou as vendas desse pequeno livro: de acordo com o site 9 feito especialmente para a obra pela editora Cosac Naify, mais de 100 mil cópias foram vendidas entre França e Alemanha, e no Brasil a cifra já ultrapassa 22 mil exemplares. ${ }^{10}$ Assim, é interessante observar como uma experiência tão pessoal quanto escrever uma carta para a mulher amada se revela, a meu ver, uma peça cultural paradigmática; algo que, tanto em seu conteúdo quanto em sua recepção pelo público internacional, nos diz muito sobre como se dão as relações de gênero no seio de certos casais e também sobre os ideais amorosos/ românticos pelos quais escolhemos construir nossas narrativas e nossos olhares.

\section{Notas}

${ }^{1}$ Nascido Gerhard Horst, o autor adotou o nome André Gorz e também o pseudônimo Michel Bosquet em muitos de seus escritos.
2 Josué Pereira SILVA, 2008, p. 75.

3 "compreendi com você que o prazer não é algo que se tome ou que se dê. Ele é um jeito de dar-se e de pedir ao outro a doação de si. Nós nos doamos inteiramente um ao outro" (p. 9).

${ }^{4}$ Anthony GIDDENS, 2003.

${ }^{5}$ Instituição fundada em 1949, voltada para a integração mundial, segundo Gorz.

${ }^{6}$ Roland BARTHES, 1981.

${ }^{7}$ Mariza CÔRREA, 2003.

${ }^{8}$ Para uma interessante reflexão sobre a história de Romeu e Julieta como metáfora para a instituição do individualismo e do estado moderno, ver Viveiros de CASTRO e Bezaquem de ARAÚJO, 1977.

${ }^{\circ}$ COSAC NAIF, 2010.

10 ÚLTIMO SEGUNDO, 2010.

\section{Referências}

BARTHES, Roland. Fragmentos de um discurso amoroso. Rio de Janeiro: Livraria Francisco Alves, 1981.

CASTRO, Viveiros de; ARAÚJO, Eduardo Bezaquem de. "Romeu e Julieta e a origem do estado". In: VELHO, Gilberto. Arte e sociedade: ensaios de sociologia da arte. Rio de Janeiro: Zahar Editores, 1977. p. 130-169.

CORRÊA, Mariza. Antropólogas \& antropologia. Belo Horizonte: UFMG, 2003.

COSAC NAIF. "André Gorz". Disponível em: <http:/ /editora.cosacnaify.com.br/legacy/gorz/>. Acesso em: 10 set. 2010.

GIDDENS, Anthony. A transformação da intimidade. São Paulo: Unesp, 2003.

SILVA, Josué Pereira. "Posfácio". In: GORZ, André. Carta a D.: história de um amor. Tradução de Celso Azzan Jr. São Paulo: Annablume; Cosac Naify, 2008. 78 p.

ÚLTIMO SEGUNDO. "Carta a $D$. vira best seller no Brasil". Disponível em: <http://ultimosegun do.ig.com.br/mauricio_stycer/2008/08/21/ carta_a_d_vira_best seller_no_brasil_1588329.html > . Acesso em: 10 set. 2010.

Fernanda Azeredo de Moraes Universidade Federal de Santa Catarina 